\title{
An Acid-tolerant Iron-oxidizing Metallogenium
}

\author{
By F. WALSH AND R. MITCHELL \\ Laboratory of Applied Microbiology, Division of Engineering and \\ Applied Physics, Harvard University, Cambridge, Massachusetts 02 I38, U.S.A.
}

(Accepted for publication 27 April 1972)

\begin{abstract}
S UMMAR Y
A filamentous iron bacterium similar to some reported forms of Gallionella and Metallogenium has been isolated in pure culture from a number of widely distributed iron-bearing streams. This organism grows in multi-branching colonies of iron-encrusted filaments (diameter: $0 \cdot \mathrm{I}$ to $0.4 \mu \mathrm{m}$ ) without a conventional cell body. Differentiation of this bacterium from Gallionella and other forms of Metallogenium is based upon morphology, growth requirements, and ability to catalyse iron oxidation under meso-acidic conditions.
\end{abstract}

\section{INTRODUCTION}

Gallionella ferruginea has been characterized as a bean-shaped cell with twisted non-living stalks exuded from side or ends (Cholodny, 1924). These stalks are the site of precipitation of ferric iron compounds as demonstrated by a strong Prussian blue reaction with ferrocyanide. Pringsheim (I 949) classified $G$. ferruginea as an iron bacterium because of its ability to precipitate iron from iron-bearing waters. Both Pringsheim (I949) and Vatter \& Wolfe (I956) concluded that the stalks were non-living exudates of the cell. More recently, van Iterson (1958), Balashova (1967, 1968, 1969), Engel \& Hanert (I967) and Hanert (I968, I970) have suggested that the stalks of Gallionella may be living elements.

The question of the viability of these stalks has been complicated by Zavarin's (196I) suggestion that the forms of Gallionella which have viable stalks may be Metallogenium spp. He described Metallogenium symbioticum as a filamentous organism growing in iron-rich environments with Leptothrix which oxidizes and precipitates manganese. The organism $M$. symbioticum grew in two forms: as filaments without cells and as cells which sprouted filaments. Zavarzin observed (1964) that $M$. symbioticum grew symbiotically with an unspecified fungus. Dubinina (I969) reported that Metallogenium sp. grown on horse serum, could be obtained in pure culture and did not lose its ability to oxidize or precipitate manganese. She also noted (1970) a number of pleomorphic filamentous forms in older cultures grown on manganese which were of uneven thickness and contained electron-dense granules.

The organism described here grows as filaments encrusted with ferric iron compounds. It is morphologically similar to the rose garland form of Metallogenium described by Dubinina (1970). It oxidizes and precipitates ferrous iron compounds, lacks a conventional cell body and grows as filaments which are self-reproducing units. We have classified it as an iron-oxidizing strain of Metallogenium.

\section{METHODS}

Organism sources. The iron content and $\mathrm{pH}$ of samples from five widely separated ironbearing ground waters, less than I week old when received, were measured. The samples

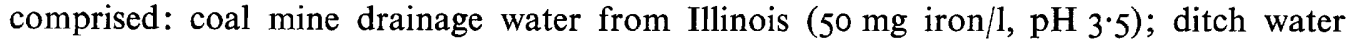


Table 1. Growth of the iron-oxidizing organism on various media

Isolates were initially grown on the minimal medium (MM) buffered with phthalate and containing formalin (see text).

\begin{tabular}{l}
\multicolumn{1}{c}{ Medium } \\
Minimal medium (MM) \\
Minimal medium \\
MM $+0.4 \%$ phthalate \\
MM $+0.2 \%$ phthalate \\
MM + agarose $(1 \cdot 5 \%$ ) \\
MM + glass beads \\
MM + glass beads
\end{tabular}

Initial
$\mathrm{pH}$
$6 \cdot 8$
$4 \cdot 0$
$4 \cdot \mathrm{I}$
$4 \cdot \mathrm{I}$
$6 \cdot 5$
$6 \cdot 5$
$4 \cdot 2$

Ferrous iron concentration $(\mathrm{mg} / \mathrm{l})$

\begin{tabular}{ccccc}
\hline 0 & I0 & 40 & 150 & 300 \\
- & + & $(+)$ & - & - \\
- & + & + & - & - \\
- & $(+)$ & ++ & +++ & +++ \\
- & $(+)$ & ++ & ++ & $(+)$ \\
- & - & $(+)$ & ++ & $(+)$ \\
- & - & + & $(+)$ & - \\
- & - & + & + & -
\end{tabular}

from New Hampshire ( $\mathrm{I} \cdot 5 \mathrm{mg}$ iron/l, $\mathrm{pH} 6 \cdot 7)$; coal mine drainage water from W. Virginia (I $25 \mathrm{mg}$ iron/1, pH 2.5); zinc mine drainage water from New Jersey (27 mg iron/1, pH 5.7); and stream water from Vermont $(2.5 \mathrm{mg}$ iron/1, $\mathrm{pH} \mathrm{6.8)}$. The first two samples were obtained in October, the third in September, the fourth in August and the last in May.

Organism isolation. The isolation medium contained: $\left(\mathrm{NH}_{4}\right)_{2} \mathrm{SO}_{4}, 0 . \mathrm{I} \%, \mathrm{CaCO}_{3}, 0.0 \mathrm{\%}$ $\mathrm{MgSO}_{4} .7 \mathrm{H}_{2} \mathrm{O}, 0.02 \%$; $\mathrm{KH}$ phthalate, $0.4 \%$; $\mathrm{KH}_{2} \mathrm{PO}_{4}$, $0.00 \mathrm{I} \%$. This medium was autoclaved before addition of ferrous iron, which was prepared as a $9 \% \mathrm{FeSO}_{4} \cdot{ }_{7} \mathrm{H}_{2} \mathrm{O}$ solution acidified to $\mathrm{pH}$ I with conc. $\mathrm{H}_{2} \mathrm{SO}_{4}$ before autoclaving. The isolation medium was finally adjusted to $\mathrm{pH} 4 . \mathrm{I}$ with $0.2 \mathrm{~N}-\mathrm{NaOH}$. During initial isolation of organisms, but not for routine cultivation, $0.4 \%$ formalin was added. Nunley \& Krieg (I 968 ) used $0.4 \%$ formalin to obtain cultures of Gallionella ferruginea free from heterotrophic contaminants. We observed that this concentration of formalin inhibited growth of the acid-tolerant ( $\mathrm{pH} 3.5)$ nonfilamentous iron bacterium Thiobacillus ferrooxidans.

A $0.5 \mathrm{ml}$ inoculum was added to $100 \mathrm{ml}$ of this phthalate isolation medium with formalin and incubated at $22{ }^{\circ} \mathrm{C}$. Isolates of a filamentous iron bacterium were obtained from all five sources after three subculture transfers.

Two other media (Table I), both without phthalate but with the concentrations of salts listed above, were used. The first was identical with the isolation medium except that instead of phthalate it contained $10 \mathrm{~g}$ of $0.1 \mathrm{~mm}$ glass beads/100 $\mathrm{ml}$. In the second, $100 \mathrm{ml}$ of the salts solution without phthalate or iron was added to $50 \mathrm{ml}$ of solidified $\mathrm{I} \cdot 5 \%$ agarose in a $250 \mathrm{ml}$ flask to which the ferrous iron had been added just before solidification.

Preparation for morphological observation. Samples $(20 \mathrm{ml})$ of 3-day cultures from the phthalate growth medium were centrifuged at $13000 \mathrm{~g}$. The resultant pellet was washed gently with $0.05 \%$ oxalic acid solution and with the sterile growth medium (without iron). This washing was repeated three times and the filaments observed by phase contrast and electron microscopy (Hitachi HU II). Incomplete removal of the ferric iron from the filaments was shown by a positive Prussian blue reaction with potassium ferrocyanide. We tried washing with other organic and inorganic acids but found that concentrations sufficient to dissolve the ferric iron precipitate lysed the filaments, as did higher concentrations of oxalic acid.

Organism-growth. We measured oxygen uptake, DNA and protein production, biomass and ferrous iron oxidation catalysis. A Gibson micro-respirometer was used to measure oxygen uptake. DNA and cell-protein production were followed by using the diphenylamine method (Burton, I956) and Folin's phenol reagent (Lowry, Rosebrough, Farr \& Randall, 1951), respectively. Both DNA and protein determinations were made on washed bacteria 
from Io $\mathrm{ml}$ samples because high ferrous iron concentrations were found to interfere. Ferrous iron oxidation catalysis was measured by following ferrous iron concentrations by acid permanganate titration of a $\mathrm{I} \mathrm{ml}$ sample using an $o$-phenanthroline indicator; the concentration of iron in solution, measured by atomic absorption at $247 \cdot 7 \mathrm{~nm}$ did not change significantly during the test period.

A $0.5 \mathrm{ml}$ inoculum was used in the catalysis experiments. Determination of the number of active filaments in this inoculum was difficult. Estimation of cell numbers by plate counts was impossible because the organism does not form conventional colonies on solid media. We estimated the number of filaments by a most-probable-number technique in the phthalate-iron medium, using pipettes with especially broad tips. By this method we observed that 5 -day cultures reached a relatively stable population size of $10^{5}$ viable filaments $/ \mathrm{ml}$, provided the initial ferrous iron concentration was $250 \mathrm{mg} / \mathrm{l}$. This method was not reliable because shaking broke the filaments into smaller viable units. The protein concentration of the 5-day cultures was constant at $0.02 \mathrm{mg} / \mathrm{ml}$.

For biomass determination, which was hampered by the ferric iron precipitate on the filaments, the pellet obtained by centrifuging $20 \mathrm{ml}$ of a 5 -day culture was weighed after drying overnight at $70^{\circ} \mathrm{C}$; biological material should not have been lost at this temperature. However, not all of the water of hydration may have been driven from the iron precipitate. The weighed pellet was suspended in $0 \cdot \mathrm{I} \mathrm{N}^{\mathrm{N}}-\mathrm{H}_{2} \mathrm{SO}_{4}$ and the total iron content measured by atomic absorption spectrometry. The iron salts on the filaments may have been any combination of the hydrated forms of ferric hydroxide, carbonate, phosphate, or sulphate. Of these an equivalent of iron would weigh most as ferric sulphate and least as ferric hydroxide. The difference between the pellet weight (average $702 \mathrm{mg} / \mathrm{l}$ ) and the calculated weight of ferric sulphate (average $62 \mathrm{I} \mathrm{mg/l}$ ) or ferric hydroxide (average $334 \mathrm{mg} / \mathrm{l}$ ) gave the range of biomass produced in 5 days. The percent biological material in the pellet thus ranged from $\mathrm{I} 2$ to $48 \%$.

Sensitivity to antibiotics. The filamentous iron bacterium was tested for sensitivity to penicillin and chloramphenicol in the phthalate medium at $\mathrm{pH} 4 . \mathrm{I}$. The penicillin strength varied from 8 to $33 \mathrm{I}$ units $/ \mathrm{ml}$; the chloramphenicol from 0.0025 to $0.025 \mathrm{mg} / \mathrm{ml}$. Penicillin at 83 units $/ \mathrm{ml}$, and chloramphenicol at $0.005 \mathrm{mg} / \mathrm{l}$, inhibited growth of acid mine water heterotrophs which were cultured routinely on the phthalate medium.

Filterability. Cultures of the filamentous iron bacterium were passed sequentially through a series of six Millipore filters with pore sizes from $\mathrm{I} \cdot 2$ to $0.025 \mu \mathrm{m}$. Inocula from each of the filtrates were added to $100 \mathrm{ml}$ of fresh phthalate medium. The original culture was also passed through each filter-size separately, the only difference being that cultures passed through only one filter-size grew more quickly.

\section{RESULTS}

Isolation. The isolates obtained from the five water samples were morphologically similar and had similar abilities to catalyse ferrous iron oxidation under meso-acidic conditions $(\mathrm{pH} 4 \cdot \mathrm{I})$. They would not grow in any medium without ferrous iron. Culture purity of the isolates was indicated by the absence of contaminant growth on the following media: Chlorella agar (Difco); Nitrosomonas medium (Pramer \& Schmidt, I964); nutrient agar (Difco); Sabouraud's dextrose agar (Difco); Thiobacillus agar (Burnett, Pelczar \& Conn, I957); thioglycollate medium (Difco); Thiobacillus ferrooxidans $9 \mathrm{~K}$ medium (Silverman \& Lundgren, 1959); trypticase soy broth supplemented with $0.5 \%$ yeast extract (Difco); Wolfe's medium with ferrous sulphide (Kucera \& Wolfe, I957); our culture media (Table I) without ferrous iron. 


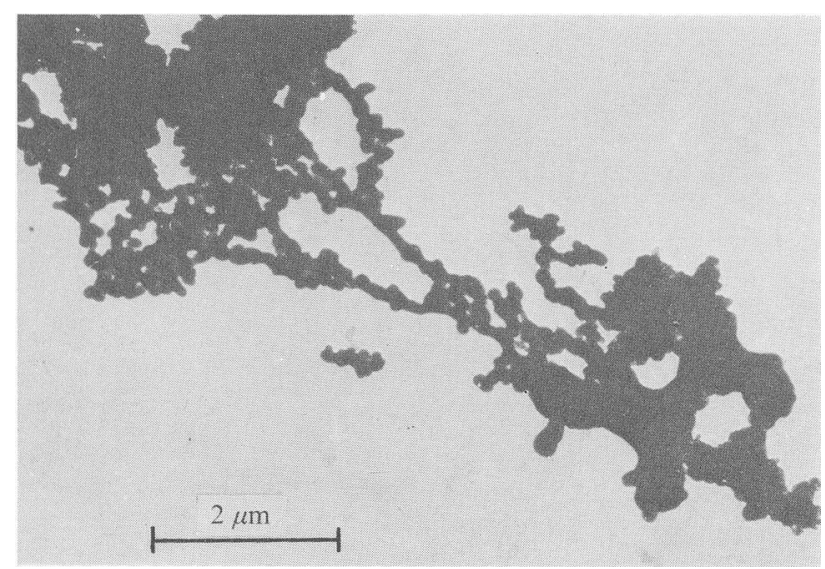

Fig. I. Electron micrograph of filaments taken directly from phthalate-buffered growth medium and washed with $0.05 \%$ oxalic acid.

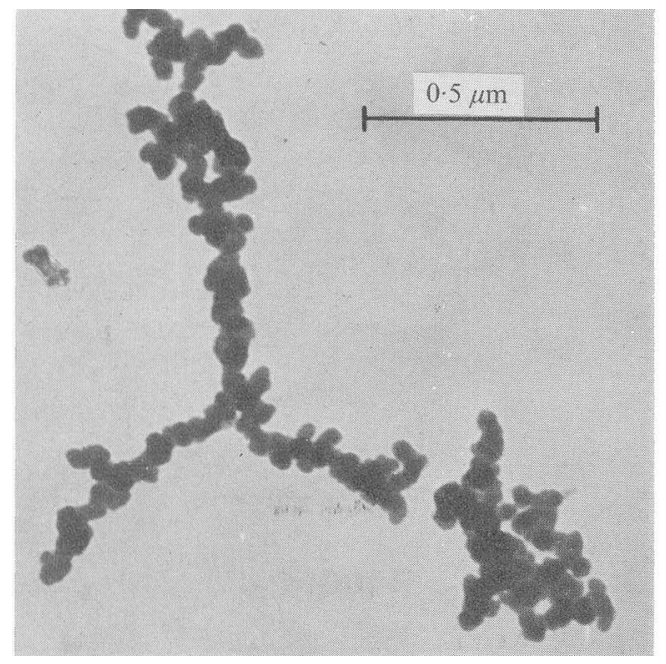

Fig. 2

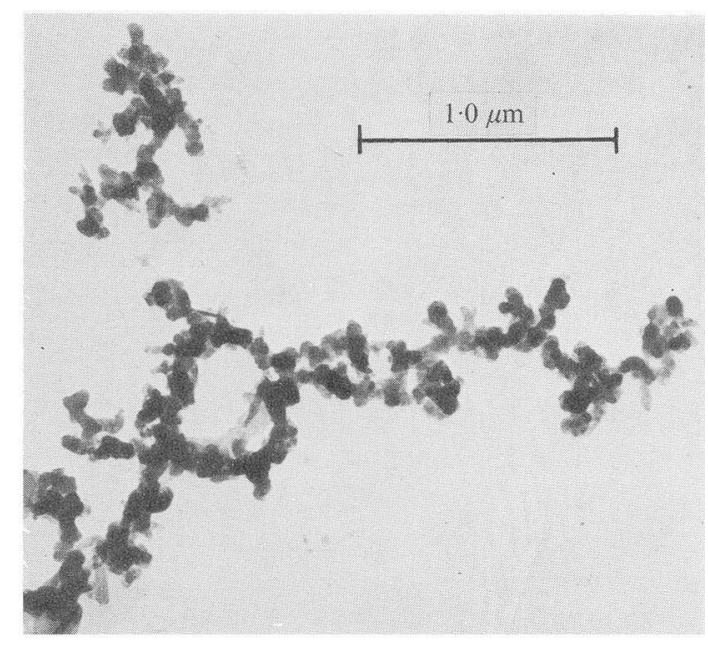

Fig. 3

Fig. 2. Electron micrograph of a single filament washed three times with $0.05 \%$ oxalic acid solution.

Fig. 3. Electron micrograph of a mass of filaments, morphologically similar to the rose garland form of Metallogenium reported by Dubinina (1970).

Morphology. The bacterial growth in the liquid phthalate medium appeared as a rusty flocculent precipitate. When this was washed carefully with $0.05 \%$ oxalic acid solution, the filamentous organisms (diameter: 0.1 to $0.4 \mu \mathrm{m}$ ) could be seen under phase contrast. We have never observed conventional cell body structures. Fig. I is an electron micrograph of acid-washed filaments from the phthalate medium. Fig. 2 shows a single filament almost free of iron precipitate. The electron-dense granules at irregular intervals along the filament may mark the sites of future filament growth. With the electron microscope a partially cleaned bacterial mass appeared to contain a number of interwoven branching filaments of various lengths and diameters without a central locus of radiation (Fig. 3).

Acid tolerance. The organism has a wide $\mathrm{pH}$ tolerance $(3.5$ to 6.8$)$ with growth optimum 


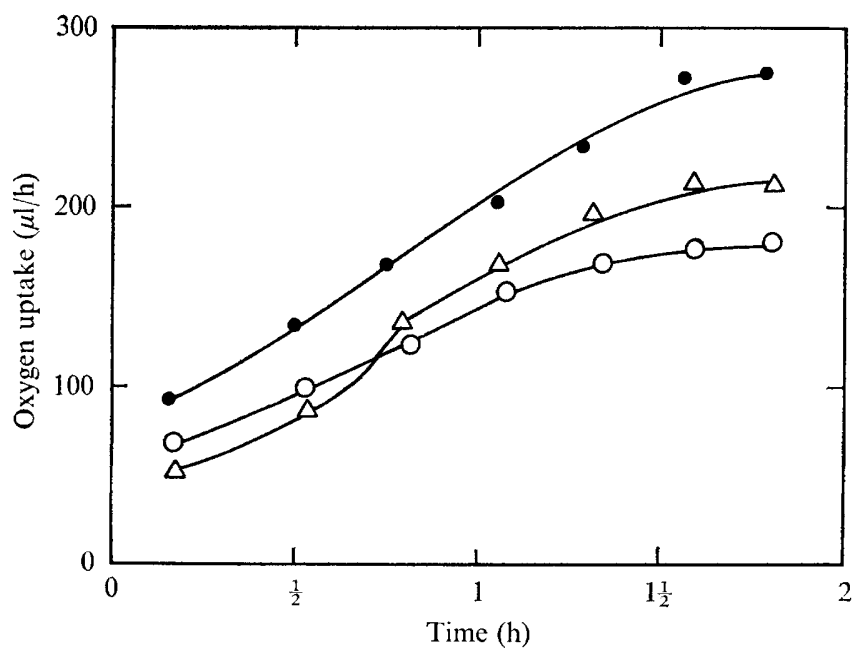

Fig. 4. Effect of initial ferrous iron concentration on respiration rates. Data corrected for abiotic oxygen uptake. Initial $\mathrm{pH}_{4} . \mathrm{I}$ buffered with $0.024 \mathrm{M}$-phthalate. $\triangle-\triangle, 40 \mathrm{mg}$ ferrous iron/l; $300 \mathrm{mg}$ ferrous iron/l; $\mathrm{O}-\mathrm{O}, 900 \mathrm{mg}$ ferrous iron/l.

at $\mathrm{pH} 4 \cdot \mathrm{I}$. Phthalate $(0.024 \mathrm{M})$ was used to buffer the medium at this $\mathrm{pH}$ value; significant growth did not occur when acetate, citrate or phosphate were substituted for phthalate, or at less than $\mathrm{pH} 3.5$. The organism did not grow in the phthalate medium in the absence of ferrous iron.

Ferrous iron inhibition. In the phthalate $(0.024 \mathrm{M})$ at $\mathrm{pH} 4 \cdot \mathrm{I}$ good growth of the organism was observed for initial ferrous iron concentrations as high as $400 \mathrm{mg} / \mathrm{l}$. In its absence, growth was inhibited at initial ferrous iron concentrations greater than $100 \mathrm{mg} / \mathrm{l}$ with a growth optimum of $40 \mathrm{mg} / 1$. Growth at ferrous iron concentrations as high as $150 \mathrm{mg} / \mathrm{l}$ in the absence of phthalate could be obtained when the medium contained glass beads or when the iron was incorporated in an agarose layer. The phthalate seemed to form a reversible phthalate-iron complex which limited the ferrous iron available.

The rate of oxygen uptake by the filamentous bacterium was dependent on initial ferrous iron concentrations (Fig. 4). Ferrous iron concentrations greater than 450 or less than $50 \mathrm{mg}$ iron/l decreased oxygen uptake rates below the maximum uptake rates observed at $300 \mathrm{mg}$ iron/l. The inhibitory effect of initial ferrous iron concentrations as high as $600 \mathrm{mg}$ iron/1 was decreased by increasing the phthalate concentration to $0.045 \mathrm{M}$, probably due to the formation of a phthalate-iron complex.

Iron oxidation rate. At an initial $\mathrm{pH}_{4} \cdot \mathrm{I}$ buffered with $0.024 \mathrm{M}$-phthalate and an initial ferrous iron concentration of $400 \mathrm{mg} / \mathrm{l}$, we observed that the rate of ferrous iron oxidation in the presence of the iron bacterium was $22 \mathrm{mg} / 1$ day for the first $50 \mathrm{~h}$ (Fig. 5) while the abiotic rate was measured at $0.9 \mathrm{mg} / \mathrm{l}$ day. In this experiment an inoculum size of $0.01 \mathrm{mg}$ bacterial protein/IO0 $\mathrm{ml}$ was used.

The rate of DNA and cell protein production mirrored the rate of iron oxidation. The cell-protein concentration increased to $22 \mathrm{mg} / \mathrm{l}$ and the DNA level to more than $5.4 \mathrm{mg} / \mathrm{l}$ in $50 \mathrm{~h}$ for the iron oxidation rate of $22 \mathrm{mg} / \mathrm{l}$ day reported above. During the same time period, biomass production was between $8 \mathrm{I}$ and $368 \mathrm{mg} / \mathrm{l}$ depending on whether the hydrated ferric iron precipitate on the filaments was predominantly a hydroxide or a sulphate. The theoretical content of cell protein in the biomass was thus between 6 and $27 \%$. 


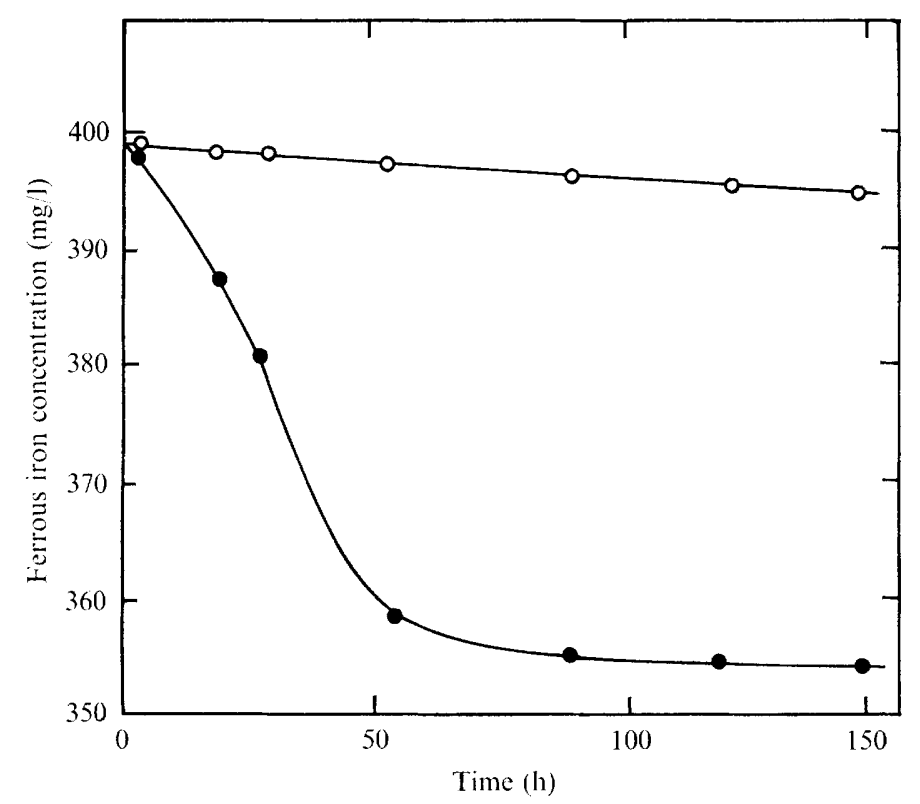

Fig. 5. Ferrous iron oxidation at $\mathrm{pH}_{4} \cdot 1$ in the presence of the stalked iron bacterium. Ferrous iron concentration: in the presence of the bacterium, - in the sterile control, $\bigcirc-O$.

Typical characteristics. The filamentous iron bacterium was insensitive to less than 150 units of penicillin $/ \mathrm{ml}$, but some filament growth was observed at concentrations as high as 33I units $/ \mathrm{ml}$. Growth of heterotrophs isolated from acidic mine drainage samples was entirely inhibited by concentrations greater than 83 units penicillin $/ \mathrm{ml}$ in the phthalate medium. The iron bacterium and the heterotrophs were sensitive to chloramphenicol, with strong inhibition at concentrations as low as $0.005 \mathrm{mg} / \mathrm{ml}$.

The smallest viable unit of the filamentous iron bacterium has not been identified. However, filaments producing growth passed through a $0.22 \mu \mathrm{m}$ pore-size filter but not through a $0.025 \mu \mathrm{m}$ filter. The smallest viable filaments thus had a diameter between 0.025 to $0.22 \mu \mathrm{m}$, although their minimal length is still undetermined.

\section{DISCUSSION}

The bacterium described in this study differs from Gallionella ferruginea as described by Cholodny (1924), Pringsheim (I949) and Vatter \& Wolfe (I956) in its absence of a conventional cell body and in its growth optimum of $\mathrm{pH} 4^{\cdot} \cdot \mathrm{I}$. It resembles the unusual Gallionella forms of van Iterson (1958), Balashova (I968) and Hanert (I968) in that the filaments are viable units. It differs from Thiobacillus ferrooxidans in morphology and in its ability to grow in the presence of $0.4 \%$ formalin. It also differs from Caulobacter (Poindexter, 1964) in its requirement of ferrous iron for growth and in the encrustation of the filaments with ferric iron compounds. It is morphologically similar to the rose garland form of the manganese bacterium, Metallogenium, described by Dubinina (1970). However, we observed only infrequent growth of this filamentous iron bacterium in the Metallogenium symbioticum medium described by Zavarzin (1964) which contains starch and manganese. Thus, while our filamentous iron bacterium is similar to some of the previously reported forms of Metallogenium, it appears to be sufficiently different to be considered a new strain (Table 2).

The role of ferrous iron in the metabolism of this filamentous iron bacterium is not clear. 
Table 2. Comparison of the characteristics of our filamentous iron bacterium with those of Gallionella and Metallogenium

\begin{tabular}{|c|c|c|c|}
\hline & $\begin{array}{l}\text { Filamentous } \\
\text { iron bacterium }\end{array}$ & Metallogenium & Gallionella \\
\hline Viable stalk or filament & + & + & - \\
\hline Conventional cell body & - & $(+)^{*}$ & + \\
\hline Filterability & + & + & $(-)_{\dagger}^{\dagger}$ \\
\hline Penicillin sensitive $(<\mathrm{I} 50$ units $/ \mathrm{ml})$ & - & - & + \\
\hline Utilizes iron & + & - & + \\
\hline Utilizes manganese & $(+) \ddagger$ & + & - \\
\hline
\end{tabular}

The organism apparently requires some iron for growth but is inhibited by higher iron concentrations. This dependence on, yet inhibition by, ferrous iron is similar to the response to manganese reported by Zavarzin (1964) for Metallogenium symbioticum. Further work by Dubinina (1969, 1970) has not explained the dependence of $M$. symbioticum on manganese but has shown that growth of the organism is dependent on some organic growth factor which can be supplied by symbiotic growth with fungi. Similarly, we consider the response of our filamentous iron bacterium to iron to be that of an organism which may use either iron or organic material oxidation as energy source. However, our data are not enough to identify the relative importance to it of autotrophic or heterotrophic energy-yielding metabolisms in our filamentous bacterium.

Our results, taken with the recent work of Hanert (1970) and Balashova (I967, I968, I969), suggest that those filamentous iron bacteria which lack a conventional cell body may be Metallogenium rather than Gallionella strains. The presence or absence of a conventional cell body and the filamentous form are but two genus characterizing factors. Species differentiation in Metallogenium can be based on acid tolerance, ferrous-iron tolerance, oxygen and carbon-dioxide requirements, growth medium, $\mathrm{pH}$ value requirement and ferrous iron (or manganese) oxidation catalysis rate. The filamentous iron bacterium isolated in the present study significantly catalysed iron oxidation in the range $\mathrm{pH} 3.5$ to $5^{\circ} 0$ with an optimum at $\mathrm{pH} 4 \cdot \mathrm{I}$ and was sensitive to concentrations of non-complexed ferrous iron above $50 \mathrm{mg} / \mathrm{l}$.

The authors wish to express appreciation to Dr K. C. Marshall of the University of Tasmania, Australia, for his interest and suggestions in this work. This research was supported in part by a training grant from the U.S. Environmental Protection Agency.

\section{REFERENCES}

Balashova, V. V. (I967). Structure of the stalk fibres in a laboratory culture of Gallionella filamenta. Mikrobiologiya (USSR) 36, 879-88I.

Balashova, V. V. (1968). Taxonomy of the genus Gallionella. Mikrobiologiya (USSR) 37, 590-598.

Balashova, V. V. (1969). The relationship of Gallionella to Mycoplasma. Doklady Akademii Nauk SSSR (Biological Sciences Sections) r84, 82-86.

Burnett, G. W., Pelczar, Jun., M. J. \& Conn, H. J. (1957). Manual of Microbiological Methods, p. 476. New York: McGraw Hill Book Co.

Burton, K. (1956). A study of the conditions and mechanisms of the diphenylamine reaction for the colorimetric estimation of deoxyribonucleic acid. Biochemical Journal 62, 3 I 5-3 I 7 . 
Cholodny, N. (1924). Zur Morphologie der Eisenbakterien, Gallionella und Spirophyllum. Berichte der Deutschen botanischen Gesellschaft 42, 35-44.

Dubinina, G. A. (1969). Inclusion of Metallogenium among the Mycoplasmatales. Doklady Akademii Nauk SSSR (Biological Sciences Sections) 184, 87-90.

Dubinina, G. A. (1970). Untersuchungen über die Morphologie von Metallogenium und die Beziehungen zu Mycoplasma. Zeitschrift für allgemeine Mikrobiologie 10, 309-320.

Engel, H. \& HANERT, H. (1967). Isolierung von Gallionella ferruginea Ehrenberg. Naturwissenschaften 54, I $47-148$.

HANERT, H. (1968). Untersuchungen zur Isolierung, Stoffwechselphysiologie und Morphologie von Gallionella ferruginea Ehrenberg. Archiv für Mikrobiologie 6o, 348-376.

HANERT, H. (1970). Struktur und Wachstum von Gallionella ferruginea Ehrenberg am natürlichen Standort in den ersten 6 Stunden der Entwicklung. Archiv für Mikrobiologie 75, 10-24.

VAN ITERSON, W. (1958). Gallionella ferruginea Ehrenberg in a Different Light, pp. I-I85. Amsterdam: Noord-Hollandsche Uitgevers Maatschappij.

Kucera, S. \& Wolfe, R. S. (I957). A selective enrichment method for Gallionella ferruginea. Journal of Bacteriology 74, 344-349.

Lowry, O. H., Rosebrough, N. J., FARR, A. L. \& Randall, R. J. (I95I). Protein measurement with the Folin phenol reagent. Journal of Biological Chemistry 193, 265-267.

NUNLEY, J. W. \& KRIEG, N. R.(I968). Isolation of Gallionella ferruginea by use of formalin. Canadian Journal of Microbiology 14, 385-389.

PoINDEXTER, J. S. (1964). Biological properties and classification of the Caulobacter group. Bacteriological Reviews 28, 23I-295.

Pramer, D. \& Schmidt, E. L. (I964). Experimental Soil Microbiology, p. 78. Minneapolis : Burgess Publishing Co.

Pringsheim, E. G. (I949). Iron bacteria. Biological Reviews 24, 200-245.

Silverman, M. P. \& Lundgren, D. G. (1959). Studies of the chemoautotrophic iron bacterium Ferrobacillus ferrooxidans. Journal of Bacteriology 77, 642-647.

VATTER, A. E. \& WOLFE, R. S. (1956). Electron microscopy of Gallionella ferruginea. Journal of Bacteriology 72, 248-252.

ZAVARZIN, G. A. (I96I). Budding bacteria. Mikrobiologiya (USSR) 30, 952-975.

ZAVARzIN, G. A. (1964). Metallogenium symbioticum. Zeitschrift für allgemeine Mikrobiologie 4, 390-395. 